\title{
ALK Inhibitor RO5424802
}

National Cancer Institute

\section{Source}

National Cancer Institute. ALK Inhibitor R05424802. NCI Thesaurus. Code C105615.

An orally available inhibitor of the receptor tyrosine kinase anaplastic lymphoma kinase (ALK) with antineoplastic activity. Upon administration, ALK inhibitor RO5424802 binds to and inhibits ALK kinase, which leads to a disruption of ALK-mediated signaling and eventually inhibits tumor cell growth in ALK-overexpressing tumor cells. ALK belongs to the insulin receptor superfamily and plays an important role in nervous system development. ALK dysregulation and gene rearrangements are associated with a series of tumors. Additionally, ALK mutations are associated with acquired resistance to small molecule tyrosine kinase inhibitors. 